\title{
PENGARUH STRUKTUR AKTIVA, PROFITABILITAS, UKURAN PERUSAHAAN DAN LIKUIDITAS TERHADAP STRUKTUR MODAL PADA PERUSAHAAN SEKTOR BARANG KONSUMSI YANG TERDAFTAR DI BURSA EFEK INDONESIA PERIODE TAHUN 2014- 2015.
}

\author{
Putu Artha Wirawan \\ Jurusan Pendidikan Ekonomi \\ Universitas Pendidikan Ganesha \\ Singaraja, Indonesia \\ e-mail: arthabusungbiu@yahoo.com
}

\begin{abstract}
Abstrak
Penelitian ini bertujuan untuk mengetahui (1) pengaruh struktur aktiva terhadap struktur modal (2) pengaruh profitabilitas terhadap struktur modal (3) pengaruh likuiditas terhadap struktur modal (4) pengaruh ukuran perusahaan terhadap struktur modal dan (5) pengaruh struktur aktiva, profitabilitas, ukuran perusahaan dan likuiditas terhadap struktur modal secara simultan. Jenis penelitian ini adalah klausal. Populasi dan sampel dalam penelitian ini adalah 33 perusahaan sektor barang konsumsi yang terdaftar di (BEI). Metode pengumpulan data yang digunakan adalah dokumentasi berupa data laporan keuangan perusahaan sektor barang konsumsi yang terdaftar di (BEI) tahun 2014-2015. Metode analisis data yang digunakan adalah uji t, uji $f$, regresi linier berganda dengan persamaan regresi dan koefisien determinasi. Hasil penelitian menunjukkan bahwa (1) variabel struktur aktiva berpengaruh signifikan terhadap struktur modal dengan nilai t hitung 9,654 dan signifikan 0,00 (2) variabel profitabilitas berpengaruh signifikan terhadap struktur modal dengan nilai $t$ hitung 3,226 dan signifikan 0,002 (3) variabel ukuran perusahaan berpengaruh signifikan terhadap struktur modal dengan nilai t hitung 3,223 dan signifikan 0,002 (4) variabel likuiditas tidak berpengaruh signifikan terhadap struktur modal dengan nilai t hitung 1,627 dan signifikan 0,109, dan (5) variabel struktur aktiva, profitabilitas, likuiditas dan ukuran perusahaan secara simultan berpengaruh signifikan terhadap struktur modal dengan nilai $\mathrm{F}$ hitung 63,568 dan signifikan 0,00. Besarnya koefisien determinasi 0,794 atau sebesar $79,4 \%$ sehingga dapat disimpulkan bahwa struktur aktiva, profitabilitas, likuiditas dan ukuran perusahaan secara simultan berpengaruh signifikan terhadap struktur modal.
\end{abstract}

Kata kunci: Struktur modal, perusahaan, sektor konsumsi.

This study aims to determine (1) the effect of the structure of assets on the capital structure (2) the effect of profitability on the capital structure (3) the effect of liquidity on the capital structure (4) the effect of the size of the company on the capital structure and (5) the effect of asset structure, profitability, size companies and liquidity to capital structure simultaneously. This type of research is causal. Population and sample in this research are 33 companies listed consumer goods sector in (BEI). Data collection method used is the documentation of the company's financial statement data consumer goods sector registered (BEI) in 2014-2015. Data analysis method used is the t-test, $f$, multiple linear regression equation and regression coefficient of determination. The results showed that (1) the variable asset structure significantly influence the capital structure with the t value and significant 9.6540 .00 (2) variables significantly influence the profitability of capital structure with the $t$ value and significant $3,2260,002$ (3) variable firm size significantly to the capital structure with the t value 3.223 and significant 0,002 (4) the liquidity variables no significant effect on the capital structure with the $t$ value 1.627 and significant 0.109 , and (5) variable asset 
structure, profitability, liquidity and size of enterprises simultaneously significant effect the capital structure by $\mathrm{F}$ count 63.568 and significant 0.00 . The magnitude of the coefficient of determination of 0.794 or $79.4 \%$, so it can be concluded that the structure of assets, profitability, liquidity and size of enterprises simultaneously significant effect on the capital structure.

Keywords : Capital structure, company, consumer sector.

\section{PENDAHULUAN}

Perusahaan dalam menjalankan kegiatan operasionalnya membutuhkan modal untuk pemenuhan pendanaan. Modal dapat bersumber dari dana internal dan eksternal. Sumber modal internal adalah sumber yang berasal dari kegiatan usaha dalam bentuk laba yang ditahan, namun modal yang bersumber dari internal sangat terbatas, sehingga dibutuhkan tambahan modal yang bersumber dari pihak ketiga untuk mendukung kegiatan usaha. Sumber dana eksternal adalah sumber dana yang diperoleh dari pihak eksternal atau pihak ketiga berupa hutang dan dana lain yang didapat dari supplier, bank dan pasar modal (David Sukardi dan Chrtistian Herdinata, 2009). Komposisi atau perimbangan antara dana internal dan dana eksternal akan membentuk struktur modal, hal ini sesuai yang dinyatakan oleh Arief Rahman (2013:19) bahwa "perimbangan antara sumber modal internal dan eksternal disebut srtuktur modal." Struktur modal setiap perusahaan berbeda-beda hal ini karena komposisi antara sumber dana internal dan eksternal dalam struktur modal melibatkan antara resiko dan keuntungan. Menurut Sri Dwi Ari Ambarwati (2010) lebih banyak penggunaan hutang akan meningkatkan resiko yang ditanggung, selain itu penggunaan hutang yang lebih besar juga dapat menyebabkan ekspektasi return atau pengembalian karena peningkatan ekuitas. Pengoptimalan struktur modal dilakukan dengan penambahan hutang atau penambahan dana eksternal, hal ini sesuai yang dikemukakan oleh Suan Husnan (2000) dengan adanya penambahan hutang, maka manfaat hutang tersebut akan mengantarkan pada struktur modal yang optimal. Namun penambahan hutang tidak baik dilakukan secara terus menerus, karena penambahan hutang juga harus memperhatikan faktor-faktor lain yang mempengaruhi struktur modal. Menurut Brigham dan Houston (2001) faktor-faktor yang mempengaruhi struktur modal yaitu struktur aktiva, profitabilitas, ukuran perusahaan dan likuiditas. Struktur aktiva adalah perimbangan antara aktiva lancar dan aktiva tetap. Profitabilitas adalah kemampuan perusahaan dalam menghasilkan keuntungan. Ukuran perusahaan adalah total aset yang dimiliki suatu entitas dan likuiditas adalah adalah kemampuan perusahaan dalam membayar kewajiban jangka pendek.

Pada kenyataannya berbeda yang terjadi pada perusahaan sektor barang konsumsi yang terdaftar di Bursa Efek Indonesia (BEI). Dimana penjualan perusahaan sektor barang konsumsi dari tahun 2014-2015 selalu mengalami peningkatan penjualan namun tidak diikuti oleh peningkatan struktur modal. Berikut data penjualan beberapa perusahaan sektor barang konsumsi yang terdiri dari tiga sub sektor yaitu makanan dan minuman, perlengkapan dan keperluan rumah tangga serta farmasi, yang terdaftar di Bursa Efek Indonesia (BEI) dari tahun 2014-2015 dalam jutaan rupiah, sumber www.idx.co.id. Tiga Pilar Sejahtera Food Tbk, penjualan tahun 2014 sebesar 1.254.413 dan penjualan tahun 2015 sebesar 1.757.346. Cahaya Kalbar Tbk, penjualan tahun 2014 sebesar 1.115.050 dan penjualan tahun 2015 sebesar 1.750.881. Indofood Sukses Makmur Tbk, penjualan tahun 2014 sebesar 28.662.034 dan penjualan tahun 2015 sebesar 30.552.021. Dari data penjualan beberapa perusahaan sektor barang konsumsi pada tahun 2014-2015 secara keseluruhan mengalami peningkatan, 
sehingga sektor barang konsumsi memiliki prospek yang baik. Sedangkan berikut rata-rata struktur modal perusahaan sektor barang konsumsi yang terdaftar di (BEI) pada tahun 2014-2015, sumber www.idx.co.id. Pada tahun 2014 rata-rata struktur modal perusahaan sektor barang konsumsi yaitu sub sektor makanan dan minuman 43,56\%, sub sektor perlengkapan dan keperluan rumah tangga $42,48 \%$ serta sub sektor farmasi 43,74\%. Pada tahun 2015 rata-rata struktur modal perusahaan sektor barang konsumsi yaitu sub sektor makanan dan minuman 45,73\%, sub sektor perlengkapan dan keperluan rumah tangga $43,55 \%$ serta sub sektor farmasi 44,34\%. Diketahui bahwa rata-rata struktur modal perusahaan sektor barang konsumsi dari tahun 2014-2015 mengalami fluktuasi yang cenderung menurun. Dilihat dari penjualan yang mengalami peningkatan, seharusnya akan diikuti dengan penggunaan modal tambahan dalam rangka meningkatkan produktifitas dan penjualan produk. Namun kenyataannya justru mengalami penurunan sehingga, variabel struktur modal diambil sebagai variabel terikat dalam penelitian ini. Beberapa penelitian yang dilakukan tentang strktur modal, antara lain oleh Christina dan Johan menggunakan tiga variabel bebas sebagai faktor yang mempengaruhi struktur modal yaitu profitabilitas, company's size dan pembyaran deviden. Penelitian lain yang dilakukan oleh Hasa Nurrohin (2008), variabel bebas yang digunakan adalah profitabilitas, pajak bunga kontrol kepemilikan dan struktur aktiva. Penelitian yang dilakukan oleh Bambang Supono (2009) menggunakan variabel bebas ukuran perushaan, lukuiditas, pajak bunga, pembagian deviden dan perubahan.

Sesuai dengan rumusan masalah di atas maka tujuan penelitian ini adalah untuk mengetahui pengaruh struktur aktiva terhadap struktur modal, pengaruh profitabilitas terhadap struktur modal, pengaruh ukuran perusahaan terhadap struktur modal, pengaruh likuiditas terhadap struktur modal, pengaruh struktur aktiva, profitabilitas, ukuran perusahaan
Jurnal Pendidikan Ekonomi Undiksha

Volume 9 No.1 Tahun: 2017

dan likuiditas terhadap struktur modal perusahaan secara simultan pada perusahaan sektor konsumsi yang terdaftar di Bursa Efek Indonesia periode tahun 2014-2015.

\section{METODE}

Disain penelitian ini adalah desain penelitian klausal. Desain penelitian klausal adalah hubungan yang bersifat sebab akibat, variabel bebas merupakan variabel yang mempengaruhi dan variabel terikat merupakan variabel yang dipengaruhi.

Populasi dalam penelitian ini adalah seluruh perusahaan sektor barang konsumsi yang terdaftar di (BEI) tahun 2014-2015, berjumlah 33 perusahaan. Sampel dalam penelitian ini yakni seluruh populasi yang terdiri dari 33 perusahaan sektor barang konsumsi yang terdaftar di (BEI) tahun 2014-2015.

Metode pengumpulan data dalam penelitian ini adalah dokumenter. Metode dokumenter merupakan cara pengumpulan data penelitian dengan mengkaji dokumen-dokumen yang diperlukan untuk menyimpulkan data penelitian.

Instrumen penelitian yang digunakan dalam penelitian ini ialah dokumen, yang berupa laporan keuangan tahunan perusahaan sektor barang konsumsi yang terdaftar di (BEI) tahun 2014-2015. Laporan keuangan ini diperoleh dari situs resmi idx www.idx.co.id.

Metode analisis data yang digunakan dalam penelitian ini adalah regresi linier berganda dengan menggunakan program komputer software SPSS 16.0 Windows. Analisis regresi digunakan untuk mengetahui pengaruh antara suatu variabel bebas terhadap variabel terikat. Tujuan regresi berganda adalah memprediksi besar variabel terikat menggunakan data dari dua atau lebih variabel bebas yang sudah diketahui besarnya. Adapun pengujian yang dilakukan adalah uji-t, uji-f, persamaan regresi dan koefisien determinasi. 
Uji-t digunakan untuk menganalisis pengaruh variabel bebas terhadap variabel terikat secara parsial. Hasil dari uji-t dapat dilihat dari hasil output SPSS. Bila thitung lebih besar dari ttabel (one tailed) serta tingkat signifikannya ( $p$-value) lebih kecil dari $5 \%(\alpha=0.05)$, maka hal ini menunjukkan $\mathrm{Ha} 1, \mathrm{Ha} 2, \mathrm{Ha} 3$ dan $\mathrm{Ha} 4$ diterima. Hal ini berarti ada pengaruh signifikan antara variabel independen secara parsial. Uji-t menggunakan uji ttabel pada tingkat keyakinan $5 \%$ dan tingkat kesalahan dalam analisa $(\alpha)=5 \%$, dengan ketentuan degree of freedom (df1) $=\mathrm{n}-\mathrm{k}-1$, dimana $\mathrm{n}$ adalah besarnya sampel, $\mathrm{k}$ adalah jumlah variabel. $\mathrm{t}$-tabel $=$ $\{\alpha$; df $=(n-k)\}$ Adapun keputusan hipotesis adalah sebagai berikut: $\mathrm{Ha}$ diterima apabila : t-hitung $>$ t-tabel.

Uji-f digunakan untuk mengetahui apakah model regresi dapat digunakan untuk mempengaruhi variabel terikat secara simultan atau tidak, dengan kriteria pengujian tingkat signifikan $\alpha=0,05$. Apabila $\mathrm{F}$ hitung $>\mathrm{F}$ tabel atau memiliki tingkat signifikansi $<0,05$ maka $\mathrm{HO}$ ditolak dan $\mathrm{Ha} 5$ diterima. Apabila $\mathrm{F}$ hitung $<\mathrm{F}$ tabel atau memiliki tingkat signifikansi > 0,05 maka Ha5 ditolak. Adapun cara pengujian baik dalam regresi sederhana maupun regresi berganda sama, yaitu dengan menggunakan suatu tabel yang disebut dengan Tabel ANOVA (Analysis of Variance) melalui bantuan program SPSS.

Dari hasil output SPSS, uji-F dapat dilihat nilai $F$ pada tabel ANOVA. Pengujian ini dilakukan dengan uji-F pada confident level $5 \%$ dan tingkat kesalahan analisis $(\alpha)$ $5 \%$ dengan ketentuan degree of freedom $(\mathrm{df} 1)=\mathrm{k}-1$, degree of freedom $(\mathrm{df} 2)=\mathrm{n}-\mathrm{k}$. Persamaan regresinya adalah $Y=\beta 0+$ $\beta 1 X 1+\beta 2 X 2+\beta 3 X 3+\beta 4 X 4+\mu$.
Koefisien Determinasi (Adjusted $\mathrm{R}$ Square) bertujuan untuk mengetahui seberapa besar kemampuan variabel bebas menjelaskan variabel terikat. Nilai $R$ Square berada diantara $0-1$, semakin dekat nilai $\mathrm{R}$ Square dengan 1 maka garis regresi yang digambarkan menjelaskan $100 \%$ variasi dalam Y. Sebaliknya, jika nilai $\mathrm{R}$ Square sama dengan 0 atau mendekatinya maka garis regresi tidak menjelaskan variasi dalam $Y$. Koefisien determinasi yang digunakan Adjusted $R$ Square (R2adj)..

Sebelum data dianalisis regresi linier berganda, maka harus dilakukan uji asumsi klasik. Uji asumsi klasik diperlukan untuk mengetahui apakah data sudah layak untuk analisis lebih lanjut. Dalam penggunaan regresi linear rentan dengan beberapa permasalahan yang sering timbul, sehingga akan menyebabkan hasil dari penelitian yang telah dilakukan menjadi kurang akurat. Uji asumsi klasik yang digunakan dalam penelitian ini adalah uji normalitas, uji multikolinieritas, uji heteroskedastisitas dan uji autokorelasi.

\section{HASIL DAN PEMB AHASAN Hasil Penelitian}

Pengaruh struktur aktiva, profitabilitas, likuiditas dan ukuran perusahaan secara parsial terhadap struktur modal pada perusahaan sektor konsumsi yang terdaftar di (BEI) periode tahun 2014-2015, dianalisis dengan menggunakan uji statistik tes dengan program software SPSS 16.0 Windows. Hasil analisis tersebut dapat dilihat pada tabel

4.1 .

Tabel 4.1 Hasil uji t pengaruh secara parsial struktur modal, profitabilitas, likuiditas dan ukuran perusahaan terhadap struktur modal Coefficients ${ }^{a}$

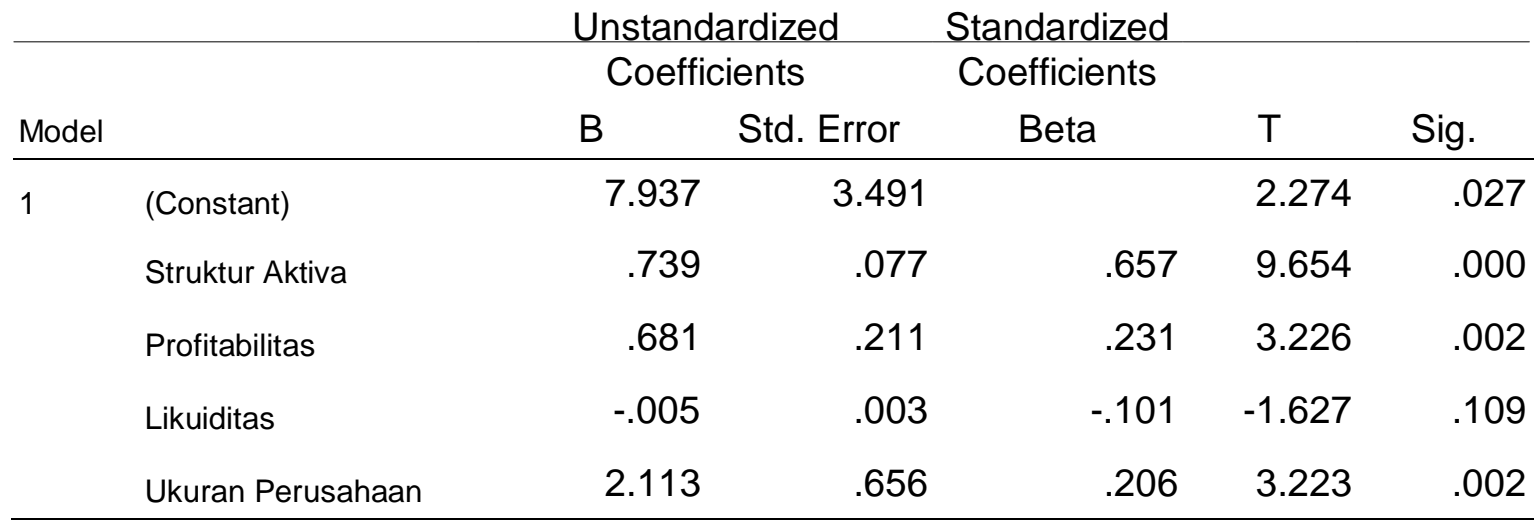

a. Dependent Variable: Struktur Modal 
Dari tabel 4.1 diketahui bahwa variabel struktur aktiva berpengaruh signifikan terhadap variabel struktur modal karena, nilai $t_{\text {bitung }}=9.654>t_{\text {tabel }}=1,997$ atau $p$-value $=0,00<a=0,05$ maka Ha1 diterima. Dapat disimpulkan bahwa variabel struktur aktiva secara parsial berpengaruh signifikan terhadap struktur modal pada perusahaan sektor konsumsi yang terdaftar di (BEI) periode tahun 2014-2015. Dari tabel tersebut diatas juga dapat diketahui, variabel profitabilitas berpengaruh signifikan terhadap variabel struktur modal. Hal ini ditunjukkan dengan nilai $t_{\text {binung }}=3.226>t_{\text {tahml }}=1,997$ atau p-value $=0,002<a=0,05$ maka Ha2 diterima. Dapat disimpulkan bahwa variabel profitabilitas secara parsial berpengaruh signifikan terhadap struktur $\mathrm{t}_{\text {tabel }}=1,997$ atau $\mathrm{p}$-value $=0,002<\mathrm{a}=$ 0,05 maka Ha4 diterima. Dapat disimpulkan bahwa variabel ukuran perusahaan secara parsial berpengaruh signifikan terhadap struktur modal pada perusahaan sektor konsumsi yang terdaftar di (BEI) periode tahun 20142015.

Untuk mengetahui pengaruh secara simultan variabel struktur aktiva, profitabilitas, likuiditas dan ukuran perusahaan terhadap struktur modal pad perusahaan sektor konsumsi yang terdaftar di (BEI) periode tahun 20142015, dilakukan dengan uji $F_{\text {Tfs }}$ dengan program software SPSS 16.0 Windows. Hasil analisis tersebut dapat dilihat pada tabel 4.2

Berdasarkan hasil analisis pada

Tabel 4.2 Hasil perhitungan uji F struktur aktiva, profitabilitas, likuiditas dan Ukuran perusahaan terhadap struktur modal.

ANOVA $^{\mathrm{b}}$

\begin{tabular}{|c|c|c|c|c|c|c|}
\hline Model & & $\begin{array}{l}\text { Sum of } \\
\text { Squares }\end{array}$ & Df & Mean Square & $\mathrm{F}$ & Sig. \\
\hline \multirow[t]{3}{*}{1} & Regression & 2554.050 & 4 & 638.513 & 63.568 & $.000^{a}$ \\
\hline & Residual & 612.717 & 61 & 10.045 & & \\
\hline & Total & 3166.767 & 65 & & & \\
\hline
\end{tabular}

a. Predictors: (Constant), Ukuran Perusahaan, Likuiditas, Struktur Aktiva, Profitabilitas

b. Dependent Variable: Struktur Modal modal pada perusahaan sektor konsumsi yang terdaftar di (BEI) periode tahun 2014-2015. Variabel likuiditas dari tabel tersebut diketahui tidak berpengaruh signifikan terhadap variabel struktur modal. Hal ini ditunjukkan dengan nilai $t_{\text {hitung }}=1.627<t_{\text {tabol }}=1,997$ atau $p$ value $=0,109>a=0,05$ maka $\mathrm{Ha} 3$ ditolak. Dapat disimpulkan bahwa variabel likuiditas secara parsial tidak berpengaruh signifikan terhadap struktur modal pada perusahaan sektor konsumsi yang terdaftar di (BEI) periode tahun 20142015. Variabel ukuran perusahaan dari tabel tersebut diketahui berpengaruh signifikan terhadap variabel struktur modal, hal ini karena nilai $\mathrm{t}_{\text {hitung }}=3.223>$ tabel 4.2 menunjukan bahwa nilai $F_{\text {hitung }}$ $=63,568>F_{\text {tahel }}=2,51$ atau $p$-value $=$ $0,00<\boldsymbol{\alpha}=0,05$ maka Ha5 diterima. Dapat disimpulkan bahwa variabel struktur aktiva, profitabilitas, likuiditas dan ukuran perusahaan memiliki pengaruh yang signifikan secara simultan terhadap struktur modal.

Persamaan regresi yang dapat dibuat untuk menggambarkan pengaruh struktur aktiva, profitabilitas, likuiditas dan ukuran perusahaan terhadap struktur modal adalah $\hat{\mathrm{Y}}=7,937+$ $0,739 \mathrm{X}_{1+0,681} \mathrm{X}_{2}-1.627 \mathrm{X}_{\mathrm{a}}+2.113 \mathrm{X}_{4} \mu$. Konstanta sebesar 7,937 menyatakan bahwa jika variabel bebas dianggap konstan atau bernilai 0 , maka struktur 
modal adalah sebesar 7,937. Setiap ada kenaikan variabel bebas sebesar satu satuan akan meningkatkan variabel terikat yaitu struktur modal sebesar koefisien beta variabel bebas dikalikan dengan besarnya kenaikan yang terjadi.

Untuk mengetahui besarnya pengaruh struktur aktiva, profitabilitas, likuiditas dan ukuran perusahaan terhadap struktur modal, dapat digunakan analisis koefisien determinasi (Adjusted $R$ Square). Besarnya koefisien determinasi (Adjusted $R$ Square) dapat dilihat pada tabel 4.3 yaitu sebagai berikut. bahwa variabel profitabilitas berpengaruh negatif terhadap struktur modal, hal ini berbeda dengan hasil penelitian dimana profitabilitas bepengaruh positif terhadap struktur modal ditunjukan dengan nilai koefisien beta yaitu $+0,681$. Dalam kasus ini rata-rata profitabilitas perusahaan sektor konsumsi yang terdaftar di (BEI) adalah $5 \%$ dari total aktiva. Jumlah ini dirasa belum cukup untuk membiayai kegiatan usaha sehingga peminjaman dana pihak ketiga menjadi alternatif. Selain itu dengan profitabilitas yang baik menjadi sinyal positif mendapatkan kepercayaan investor untuk memberikan

Tabel 4.3 Hasil perhitungan Koefisisen Determinasi (Adjusted $R$ Square) Model Summary

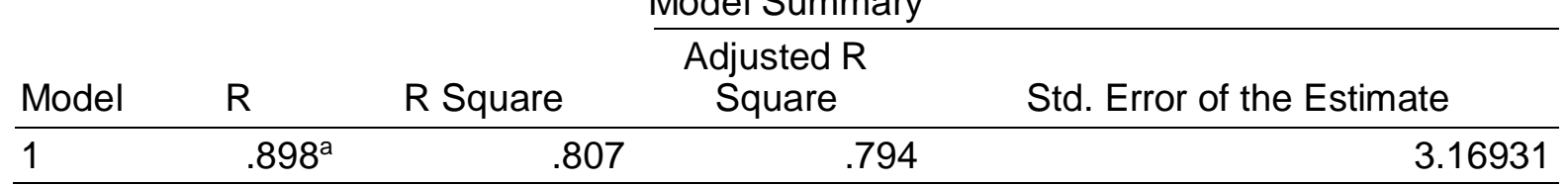

a. Predictors: (Constant), Ukuran Perusahaan, Likuiditas, Struktur Aktiva, Profitabilitas

Berdasarkan hasil analisis pada tabel 4.3 dengan menggunakan program software SPSS 16.0 Windows menunjukan bahwa besar pengaruh antara variabel struktur modal, profitabilitas, likuiditas dan ukuran perusahaan terhadap struktur modal adalah sebesar 0,794 artinya sebesar $79,4 \% \quad$ variabel struktur aktiva (X1), profitabilitas (X2), likuiditas (X3) dan ukuran perusahaan (X4) secara simultan berpengaruh terhadap Struktur modal.

\section{Pembahasan}

Hasil analisis data dalam penelitian ini menunjukkan bahwa struktur aktiva, profitabilitas dan ukuran perusahaan secara parsial berpengaruh signifikan terhadap struktur modal pada perusahaan sektor konsumsi yang terdaftar di (BEI) periode tahun 2014-2015. Temuan ini sejalan dengan hasil penelitian sebelumnya dari Murdika Alamsyah Hasan (2009) dan sesuai dengan pendapat Brigham dan Houston (2001) yang menyatakan bahwa struktur aktiva, profitabilitas dan ukuran perusahaan merupakan faktor-faktor yang mempengaruhi struktur modal. Namun Brigham dan Houston (2001) menyatakan pinjaman. Profitabilitas yang konsisten membangun kepercayaan investor bahwa perusahaan tersebut sudah menggerakkan aset yang dimiliki dalam menghasilkan keuntungan. Sehingga dalam kasus ini profitabilitas berpengaruh positif dan signifikan terhadap struktur modal.

Dari hasil penelitian ini juga diketahui bahwa variabel likuiditas tidak berpengaruh signifikan terhadap struktur modal. Berdasarkan temuan penulis dilapangan bahwa likuiditas tidak berpengaruh signifikan terhadap struktur modal pada perusahaan sektor konsumsi yang terdaftar di (BEI) periode tahun 2014-2015 dapat dijelaskan bahwa nilai konstanta yaitu $-0,005$ pada tabel Coefficients pengaruh likuiditas terhadap struktur modal, menunjukkan pengaruh negatiif antara likuiditas terhadap struktur modal tetapi pengaruhnya tidak signifikan. Nilai konstanta -0.005 memiliki pengaruh yang kecil dalam menekan struktur modal menjadi menurun artinya dalam kasus ini likuiditas tidak hanya mengakibatkan penurunan pada struktur modal tetapi, sebagian perusahaan dalam kasus ini menaikkan struktur modal akibat nilai likuiditas yang tinggi. Hal ini dapat 
diakibatkan karena dengan kemampuan membayar kewajiban jangka pendek yang baik membuat perusahaan, meningkatkan jumlah pinjaman guna menambah dana yang diinginkan sehingga dalam kasus ini likuiditas tidak berpengaruh signifikan terhadap struktur modal.

Hasil analisis data dalam penelitian ini menunjukkan bahwa struktur aktiva, profitabilitas, likuiditas dan ukuran perusahaan secara simultan memiliki pengaruh yang signifikan terhadap struktur modal pada perusahaan sektor konsumsi yang terdaftar di (BEI) periode tahun 2014-2015. Temuan ini sejalan dengan pendapat Brigham dan Houston (2001) yang menyatakan bahwa struktur aktiva, profitabilitas, likuiditas dan ukuran perusahaan merupakan variabel yang mempengaruhi struktur modal.

\section{SIMPULAN DAN SARAN Simpulan}

Berdasarkan hasil penelitian dan pembahasan dapat disimpulkan bahwa. (1) Struktur aktiva berpengaruh secara parsial terhadap struktur modal. (2) Profitabilitas berpengaruh secara parsial terhadap struktur modal. (3) Likuiditas tidak berpengaruh secara parsial terhadap struktur modal. (4) Ukuran perusahaan berpengaruh secara parsial terhadap struktur modal. (5) Struktur aktiva, profitabilitas, likuiditas dan ukuran perusahaan berpengaruh secara simultan terhadap struktur modal. Besarnya pengaruh struktur aktiva, profitabilitas, likuiditas dan ukuran perusahaan terhadap struktur modal ialah sebesar 0,794 atau sebesar $79,4 \%$, sehingga variabel struktur aktiva, profitabilitas, likuiditas dan ukuran perusahaan berpengaruh terhadap Struktur modal secara simultan.

\section{Saran}

Berdasarkan simpulan di atas, maka dapat diberikan beberapa saran sebagai berikut. (1) Bagi perusahaan, struktur aktiva, profitabilitas dan ukuran perusahaan yang dalam penelitian ini berpengaruh positif dan signifikan terhadap struktur modal agar dipertahankan oleh perusahaan, fokus perusahaan tidak saja pada penambahan
Jurnal Pendidikan Ekonomi Undiksha Volume 9 No.1 Tahun: 2017

modal untuk mendukung kegiatan usaha tetapi juga meningkatkan laba dengan cara memaksimalkan tambahan dana yang diperoleh. Faktor likuiditas juga perlu diperhatikan oleh perusahaan dalam pengambilan keputusan meningkatkan struktur modal. Dengan rata-rata likuiditas $300 \%$ dari hutang lancar menunjukan kecukupan dana dari internal perusahaan yang tinggi sehingga, akan lebih baik perusahaan menurunkan jumlah pinjaman agar keseimbangan pendanaan menjadi stabil. (2) Bagi investor, penelitian ini diharapkan dapat menjadi bahan pertimbangan para investor dalam memutuskan menanamkan modal. Investor dalam menilai kapasistas debiturnya perlu mengetahui aset tetap yang dimiliki calon debiturnya karena, aset tetap merupakan jaminan atas pinjaman yang diberikan. Bukan hanya memperhatikan jaminan, investor juga perlu mengetahui kemampuan perusahaan dalam menghasilkan laba periode sebelumnya. Perolehan laba yang konsisten di setiap periode, menunjukkan perusahaan sudah memaksimalkan aset yang dimiliki untuk menghasilkan laba. Dalam mengambil keputusan investasi, investor juga harus mempertimbangkan jumlah pinjaman yang diberikan sesuai dengan kapasitas aset yang dimiliki debitur sehingga akan lebih menurunkan resiko jika debitur tidak mampu membayar kewajiban, yang merupakan resiko kerugian bagi investor. (3) Bagi peneliti selanjutnya, penelitian ini dapat dikembangkan kembali oleh para peneliti selanjutnya agar, mengetahui faktor faktor lain yang lebih berpengaruh terhadap struktur modal dengan menambahkan variabel baru seperti variabel pembayaran deviden dan kontrol perusahaan. Peneliti selanjutnya juga dapat memperluas sampel perusahaan yang mencakup sektor-sektor ekonomi seperti sektor industri pertanian dan sektor lain yang terdaftar di Busa Efek Indonesia. 
p-ISSN : 2599-1418

e-ISSN : 2599-1426

\section{DAFTAR PUSTAKA}

Alwi, Syafaruddin. 1999. Alat-alat Analisis dalam Pembelanjaan, Edisi Revisi. Yogyakarta : Andi Offset.

Ambarwati, Sri Dwi Ari. 2010. Manajemen Keuangan Lanjut. Yogyakarta : Graha IImu.

Astuti, Dewi. 2004. Manajemen Keuangan Lanjut. Graha Ilmu.

Atmaja, Lukas Setia. 1999. Manajemen Keuangan. Yogyakarta: Andi Offset.

Brigham, Eugene F and Louis C. Gapenski. 1999. Financial Management Theoruand Practice, Edisi Kesembilan. New York: The Dryden Press.

2001. Manajemen Keuangan,Edisi 8,Edisi Indonesia. Jakarta: Erlangga.

2006. Dasar-dasar Manajemen Keuangan, Edisi 10. Jakarta: Salemba Empat.

Christina and Johan Halim. 2008. Analysis of Relations between Determinants of Capitas/ Strucutre across Industries at Jakarta Stock Exchange. Journal of Applied Finance and Accounting. Vol. 1 No. 1 November: 99-115.

Daulay, M. Toyib. 2009. Pengaruh Size, Profitability dan Growth of Assets terhadap Struktur Modal Pada Industri Makanan dan Minuman yang Go Public di Bursa Efek Indonesia. Jurnal IImiah Abdi IImu Vol. 2 No. 2
Jurnal Pendidikan Ekonomi Undiksha Volume 9 No.1 Tahun: 2017

Ghozali, Imam. 2011. Aplikasi Analisis Multivariat dengan Program SPSS 19. Semarang: Univ. Diponegoro.

Hadianto, Bram \& Tayana, Christian. 2010. Pengaruh Risiko Sistematik, Struktur Aktiva, Profitabilitas dan Jenis Perusahaan terhadap Struktur Modal Emiten Sektor Pertambangan : Pengujian Hipotesis Static-Trde Off. Jurnal Akuntansi Vol. 2 No. 1 Mei: 15-39.

Hakim, Arief Rahman. "Alalisis Faktorfaktor yang Mempengaruhi Struktur Modal pada Perusahaan Manufaktur yang terdaftar di BEI tahun 2009" . Skripsi(tidak diterbitkan). Jurusan Manajemen, Universias Islam Negeri Syarif Hidayatullah Jakarta Halim, Abdul. 2007. Manajemen Keuangan Bisnis. Bogor : Galih Indonesia

Harahap, Sofyan Syafri. 2010. Analisis Kritis atas Laporan Keuangan, Edisi 9. Jakarta : PT Raja Grafindo Persada.

Hasan, Mudrika Alamsyah. 2006. Analisis Faktor-faktor yang Mepengaruhi Struktur Modal (Studi pada Perusahaan yang terdaftar di Bursa Efek Jakarta). Jurnal Tepak Manajerial Magister Manajemen Unri. Vol. 6 No. 6 November.

Helfert, A. Erich. 1997. Teknik Analisis Keuangan, Edisi 8. Jakarta: PT Glora Aksara.

Hosain, Faruk and Ayub Ali. 2012. Impact of Firm Specific Factors on Capital Structure Decision : An Empirical Study of Bangladesh Companies. International Journal of Business Research and Management. Vol. 3. 
p-ISSN : 2599-1418

e-ISSN : 2599-1426

Husnan, Suad. 2000. Manajemen Keuangan Teori dan Penerapan (Keputusan Jangka Panjang), Buku 1, Edisi Keempat. Yogyakarta: BPFE.

Husnan, Suad dan Enny Pudjiastuti. 2004. Dasar-dasar Manajemen Keuangan, Edisi Keempat. Yogyakarta: UPP AMP YPKN.

Kasmir. 2010. Pengantar Manajemen Keuangan. Jakarta : Kencana.

Kesuma, Ali. 2009. Analisis Faktor yang Mempengaruhi Struktur Modal Serta Pengaruhnya Terhadap Harga Saham Perusahaan Real Estate yang Go Public di Bursa Efek Indonesia.

Kodrat, David Sukardi \& Herdinata, Christian. 2009. Manajemen Keuangan based on Empirical Research. Surabaya: Graha IImu.

Madura, Jeff. 2006. Keangan Perusahaan International, Buku 2. Jakarta : Salemba Empat.

Margaretha, Farah \& Ramadhan, Aditya Rizky. 2010. Faktor-faktor yang mempengaruhi Struktur Modal pada Industri Manufaktur di Bursa Efek Indonesia. Jurnal Bisnis dan Akuntansi. Vol. 12 No. 2 Agustus: 119- 130.

Moeljadi. 2006. Manajemen Keuangan. Malang: Bayu Media Publishing

Munawir, S. 2001. Analisa Laporan Keuangan, Edisi 10. Yogyakarta : Liberti.

Nachrowi dan Usman. 2006. Pendekatan Populerdan Praktis Ekonometrika untuk Analisis Ekonomidan Keuangan. Jakarta: LP-FEUI.
Jurnal Pendidikan Ekonomi Undiksha Volume 9 No.1 Tahun: 2017

Nugroho, Asih Suko. 2006. Analisis Faktor-faktor yang Mempengaruhi Struktur Modal Perusahaan Properti yang Go-Public di Bursa Efek Jakarta untuk Periode Tahun 1994-2004. Thesis, Program Studi Magister Manajemen. Universitas Diponegoro.

Nurrohim KP, Hasa.. 2008. Pengaruh Profitabilitas, Fixed Asset Ratio, Kontrol Kepemilikan dan Struktur Aktiva terhadap Struktur Modal pada Perusahaan Manuaktur di Indonesia. Kajian Bisnis dan Manajemen. Vol. 10 No. 1 Januari.

Riyanto, Bambang. 2001. Dasar-dasar Pembelanjaan Perusahaan, Edisi keempat. Yogyakarta : BPFE.

Riyanto, Bambang. 2005. Dasar-dasar Pembelanjaan Perusahaan, Edisi 2, Cetakan 4. Jakarta: Yayasan Badan Penerbitan CSES Press.

Rodoni, Ahmad dan Maratush Sholihah. 2006. Pengujian Empiris Balance Theory, Pecking Order Theory dan Signalling Theory pada Struktur Modal Perusahaan di Indonesia.Etikonomi. Vol. 5 No. 1 April: 17-30.

Rodoni, Ahmad dan Indoyama Nasaruddin. 2007. Modul Manajemen Keuangan. Jakarta.

Rodoni, Ahmad dan Herni Ali. 2010. Manajemen Keuangan, Edisi Pertama. Jakarta : Mitra Wacana Media.

Santoso, Singgih. 2012. Buku Latihan SPSS Statistik Parametrik. Jakarta: PT Alex Media Komputindo.

Sarma, L. V. L. N., Sarada Lellapalli dan Ramana V. Lellapalli. 2010. Factors Influencing Capital Structures : an Analysis of Companies in Malaysia. Unitar EJournal. Vol. 6. No. 2. Juni. 
p-ISSN : 2599-1418

e-ISSN : 2599-1426

Sartono, Agus. 2001. Manajemen Keuangan dan Aplikasi. Yogyakarta: BPFE

Seftianne dan Ratih Handayani. 2011. Faktor-faktor yang Mempengaruhi StrukturModal pad Perusahaan Manufaktur. Jurnal Bisnis dan Akuntansi. Vol.13. No. 1. April : 3956.

Sugiyono 2010. Metode Penelitian Kuantitatif \& RND. Bandung: Alfabeta 2009. Statistika untuk Penelitian. Bandung: Alfabeta

Sjahrial, Darmawan. 2008. Manajemen Keuangan, Edisi Kedua. Jakarta: Mitra Wacana Media.

Suliyanto. 2011. Ekonometrika Terapan Teori dan Aplikasi dengan SPSS.Yogyakarta: Andi.

Supeno, Bambang. 2009. Analisis Faktorfaktor yang Mempengaruhi Struktur Modal Perusahaan Sektor Makanan dan Minuman pada Bursa Efek Jakarta (BEJ). Jurnal Tepak Manajemen Bisnis. Vol. 1. No. 1 Januari.
Jurnal Pendidikan Ekonomi Undiksha Volume 9 No.1 Tahun: 2017

Tampubolon, Manahan P. 2005. Manajemen Keuangan Konseptual Problem dan Studi Kasus. Bogor: Galih Indonesia.

Walsh, Ciaran. 2003. Key Management Ratio, Edisi Ketiga. Erlangga.

Weston, J. Fred dan Thomas E. Copeland. 1995. Manajemen Keuangan, Edisi Kesembilan, Jilid 1. Jakarta: Binarupa Aksara.

1997. Manajemen Keuangan, Edisi Kesembilan, Jilid 2. Jakarta:

Binarupa Aksara.

Yovin, Devi dan Ni Putu Santi Suryantini. 2012. Faktor-faktor yang Berpengaruh Terhadap Struktur Modal pada Perusahaan Foods and Beverages yang Terdaftar di Bursa Efek Indonesia.

www.idx.co.id, mengunduh data laporan keuangan 